\title{
Immunogenetic analysis of gastric MALT lymphoma-like lesions induced by Helicobacter pylori infection in neonatally thymectomized mice
}

Toshiro Fukui ${ }^{1}$, Kazuichi Okazaki ${ }^{2,3}$, Hiroyuki Tamaki ${ }^{1}$, Kimio Kawasaki ${ }^{1}$, Minoru Matsuura $^{1}$, Masanori Asada ${ }^{1}$, Toshiki Nishi ${ }^{1}$, Kazushige Uchida ${ }^{1}$, Masahiro Iwano $^{1}$, Masaya Ohana ${ }^{1}$, Hiroshi Hiai ${ }^{4}$ and Tsutomu Chiba ${ }^{1}$

${ }^{1}$ Department of Gastroenterology and Endoscopic Medicine; ${ }^{2}$ Graduate School of Medicine, Kyoto University, Kyoto; ${ }^{3}$ Third Department of Internal Medicine and ${ }^{4}$ Department of Pathology and Biology of Diseases

Kansai Medical University, Osaka, Japan

\begin{abstract}
Most gastric mucosa-associated lymphoid tissue (MALT) lymphomas are caused by Helicobacter pylori $(H$. pylori) infection. We previously reported that acquired lymphoid follicles with germinal centers were induced by H. pylori infection in neonatally thymectomized (nTx) mice. In the present study, we developed gastric MALT lymphoma-like lesions in $\mathrm{nTx}$ mice by long-term $H$. pylori infection, and performed immunogenetic analyses. BALB/c mice were thymectomized on the 3rd day after birth. At 6 weeks of age, mice were orally infected with $10^{8} \mathrm{H}$. pylori and serially killed 2, 4, 6, and 12 months later. Normal BALB/c and noninfected nTx mice served as controls. Follicle formation occurred after 2 months of $H$. pylori infection in the $\mathrm{nTx}$ mice. Follicle formation and infiltration of intraepithelial lymphocytes progressed in a time-dependent manner. Lymphoepithelial lesions, a characteristic feature of MALT lymphoma, also occurred in a time-dependent manner (100\% at 12 months). Serum immunoelectrophoresis revealed a monoclonal band (M-protein) in 30\% (3/10) of mice 6 months after infection. M-protein-positive mice had amplification of one or two IgM and/or IgG heavy-chain genes in the gastric B lymphocytes, as determined with polymerase chain reaction, suggesting mono- or oligoclonality. Overexpression of $\mathrm{Bcl}-\mathrm{X}_{\mathrm{L}}$ protein was immunohistologically observed in the infiltrating $\mathrm{B}$ lymphocytes and in some follicular B lymphocytes in $80 \%(8 / 10)$ of the cases at 12 months. Thus, $H$. pylori infection is involved in the development of gastric MALT lymphoma-like lesions in nTx mice. Our mouse model is useful for clarifying the pathogenetic mechanism of gastric MALT lymphoma by $\mathbf{H}$. pylori infection.
\end{abstract}

Laboratory Investigation (2004) 84, 485-492, advance online publication, 16 February 2004; doi:10.1038/labinvest.3700056

Keywords: $\mathrm{Bcl}-\mathrm{X}_{\mathrm{L}}$; gastric MALT lymphoma; Helicobacter pylori; murine model; neonatal thymectomy

Accumulating evidence indicates that Helicobacter pylori ( $H$. pylori) infection is involved in the pathogenesis of not only gastritis, peptic ulcers, and gastric cancer but also mucosa-associated lymphoid tissue (MALT)-type gastric B-cell lymphoma, so-called MALT lymphoma. ${ }^{1-4}$ Immunologic interactions between the host and $H$. pylori seem to have critical roles in the development of follicular gastritis, which appears to be an important condition preceding gastric MALT lymphoma. ${ }^{5}$ Recently,

Correspondence: K Okazaki, Third Department of Internal Medicine, Kansai Medical University, 10-15 Fumizono-cho, Moriguchi, Osaka, 570-8506, Japan.

E-mail: okazaki@takii.kmu.ac.jp

Received 8 September 2003; accepted 6 November 2003 published online 16 February 2004 an API2-MALT1 fusion transcript derived from $t(11 ; 18)$ was reported to be involved in the pathogenesis of $H$. pylori-uninfected gastric MALT lymphoma. $^{6,7}$ On the other hand, the pathogenesis of $H$. pylori-positive gastric MALT lymphoma without $\mathrm{t}(11 ; 18)$ remains unclear.

BALB/c mice thymectomized on the 3rd day after birth spontaneously develop autoimmune gastritis. In neonatally thymectomized (nTx) BALB/c mice, which have a Th1-predominant reaction in the stomach, CD4 ${ }^{+}$Th1 cells induce autoimmune gastritis, whereas lymphoid follicles never occur. ${ }^{8-11}$ In previous studies, we demonstrated that infection of BALB/c nTx mice with mouse-adapted $H$. pylori permitted successful colonization of $H$. pylori in the corpus, leading to the formation of follicular gastritis 2 months after infection in association with 
appearance of a Th2-type reaction. ${ }^{5,12}$ In the present study, therefore, we extended our previous findings and attempted to develop gastric MALT lymphomalike lesions in nTx mice with long-term $H$. pylori infection, and performed immunogenetic analyses.

\section{Materials and methods}

\section{Mice and Thymectomy}

Male and female BALB/c Cr.Slc mice (Japan SLC, Shizuoka, Japan) were bred in our animal facility in Kyoto University under specific pathogen-free conditions. Mice were offered commercially available food pellets (F2; Funabashi Farm, Inc., Chiba, Japan) and drinking tap water. Neonatal thymectomy was performed on the 3rd day after birth under ether anesthesia as described previously. ${ }^{8-11}$ We previously confirmed that there were no immunologic differences between male and female mice. ${ }^{8-11}$ The mice were divided into four groups $(n=10$ in each group): (i) normal (non-nTx) mice without $H$. pylori infection, (ii) normal (non-nTx) mice with $H$. pylori infection, (iii) nTx mice without $H$. pylori infection, and (iv) nTx mice with $H$. pylori infection.

\section{Bacteria and Infection}

H. pylori (TN2GF4) isolated from a patient with a duodenal ulcer was donated from M Nakao (Pharmaceutical Research Division, Takeda Chemical Industries, Ltd, Osaka, Japan). It was maintained in blood agar base no. 2 with horse serum (5\%, vol/vol) containing amphotericin B at $2.5 \mathrm{mg} / \mathrm{l}$, trimethoprim at $5 \mathrm{mg} / \mathrm{l}$, polymyxin $\mathrm{B}$ at $1250 \mathrm{IU} / \mathrm{l}$, and vancomycin at $10 \mathrm{mg} / \mathrm{l}$. The plates were incubated in a microaerophilic atmosphere at $37^{\circ} \mathrm{C}$ for $48 \mathrm{~h}$. The inoculated $H$. pylori strain, TN2GF4, was CagA and VacA positive as described elsewhere. ${ }^{13}$ Both nTx and non-nTx mice at 6 weeks of age were either orally infected with $10^{8} \mathrm{H}$. pylori organisms or given saline as described previously. ${ }^{12}$ Mice were infected with $H$. pylori in an infection-controlled animal facility of Nippon Shinyaku Co. (Kyoto, Japan). The experiments were approved by the animal research committee of Kyoto University. Infected mice were killed 2, 4, 6, and 12 months later. Colonization of H. pylori was confirmed by PCR Southern blot analysis for the urease gene using DNA extracted from the corpus mucosa. The urease gene was amplified at all time points after infection. ${ }^{12}$ Noninfected mice were killed at the same time. The sera and stomachs were stored at $-80^{\circ} \mathrm{C}$ until use. We confirmed the abnormal hyperimmune status of nTx mice by measuring the serum autoantibody levels against the parietal cells by enzyme-linked immunosorbent assay immediately before infection (6 weeks of age) as described previously. ${ }^{12}$

\section{Histology and Immunohistochemistry}

The stomach was removed from each mouse, fixed with $4 \%$ phosphate-buffered formaldehyde ( $\mathrm{pH} 7.2$ ), and prepared for histologic examination. The sections were stained with hematoxylin and eosin. Immunohistochemical staining with monoclonal antibodies (MAbs) was performed on freshly frozen sections using the avidin-biotin immunoperoxidase method as described previously. ${ }^{12}$ Briefly, freshly frozen sections were fixed in acetone for $10 \mathrm{~min}$, rinsed in phosphate-buffered saline ( $\mathrm{pH} 7.2)$, and incubated with 10\% normal rat or horse serum (as a blocking agent) for $20 \mathrm{~min}$. The sections were incubated for $1 \mathrm{~h}$ with the primary MAbs, biotinconjugated rat anti-mouse B220, CD4, CD8, and mouse anti-mouse Bcl-X MAbs (Becton \& Dickinson, Franklin Lakes, NJ, USA). For staining with anti-Bcl$\mathrm{X} \mathrm{MAb}$, we used a commercially available mouse immunoglobulin detection kit as the secondary antibody (Ab) (VECTOR MOM Immunodetection Kit, Vector Laboratories, Inc., Burlingame, CA, USA) to detect mouse primary $\mathrm{Ab}$ on mouse tissues. After incubation with the primary and secondary Abs, the sections were washed with phosphate-buffered saline and then incubated with avidin-biotin peroxidase complex (Vector Laboratories, Inc.) for $30 \mathrm{~min}$. Sections washed with phosphate-buffered saline were reacted with a fresh mixture of $0.05 \%$ $3,3^{\prime}$-diaminobenzidine and $0.005 \% \quad \mathrm{H}_{2} \mathrm{O}_{2}$ in Tris buffer $(0.05 \mathrm{M}, \mathrm{pH}$ 7.6) and then washed with distilled water. The control samples were exposed to normal rat or mouse serum instead of the primary Abs. These control samples showed no staining. Nuclei were counterstained with methylgreen-pyronin staining.

\section{Serum Immunoelectrophoresis}

To identify the monoclonality of serum immunoglobulin, immunoelectrophoresis was performed in each group 6 months after infection according to the method of Scheidegger. ${ }^{14}$ It was performed in slab gels prepared using a mixture of agar $(8 \mathrm{~g} / \mathrm{l})$ and agarose $(4 \mathrm{~g} / \mathrm{l})$ in barbital buffer $(0.06 \mathrm{M}, \mathrm{pH}$ 8.6) with antiserum to whole mouse serum (Dainippon Pharmaceutical Co., Ltd, Osaka, Japan).

\section{Reverse Transcription-Polymerase Chain Reaction (RT-PCR) for Immunoglobulin Genes}

To identify mono- or oligoclonality of the infiltrating gastric B lymphocytes, we performed RT-PCR for heavy-chain immunoglobulin genes using a commercially available kit (Ig-Prime Kits, Novagen, Madison, WI, USA) according to the manufacturer's instructions. In brief, total RNA was extracted from the murine stomach with the RNA extraction solution (ISOGEN, Nippon Gene, Tokyo, Japan), and then reverse-transcribed into complementary 
DNA with the SuperScript Preamplification System (Gibco-BRL, Gaithersburg, MD, USA). The total RNA in the reaction mixture was heated at $42^{\circ} \mathrm{C}$ for $50 \mathrm{~min}$ and at $70^{\circ} \mathrm{C}$ for another $15 \mathrm{~min}$ and then chilled on ice. Six leader sequences were set up at the $5^{\prime}$ side of mRNAs that are commonly used to amplify the mouse IgM and IgG heavy chains and two different primers of $3^{\prime}$ side specific for IgM and IgG, respectively, were set in the constant region. The primer sequences used in this study are shown in Table 1. PCR was performed with a mixture of cDNAs, $20 \mathrm{mM}$ Tris-HCl (pH 8.4), $50 \mathrm{mM} \mathrm{KCl}$, $2.5 \mathrm{mM} \mathrm{MgCl} 2,200 \mathrm{mM}$ of each deoxynucleotide triphosphate (Perkin-Elmer, Branchburg, NJ, USA), $50 \mathrm{pM}$ of each specific primer, and 1.0 U of Taq DNA polymerase (AmpliTaq Gold; Perkin-Elmer). Amplification was performed with a thermal cycler (GeneAmp PCR System 9600R; Perkin-Elmer) for 35 cycles of $20 \mathrm{~s}$ at $95^{\circ} \mathrm{C}, 1 \mathrm{~min}$ at $55^{\circ} \mathrm{C}$, and $1 \mathrm{~min}$ at $72^{\circ} \mathrm{C}$. The final cycle induced an extension step for $10 \mathrm{~min}$ at $72^{\circ} \mathrm{C}$. A $10-\mu \mathrm{l}$ aliquot of each PCR product was electrophoresed on a $2.0 \%$ agarose gel containing ethidium bromide.

\section{Results}

\section{Histopathology and Immunohistochemistry (Table 2)}

Approximately $60 \%$ of the nTx mice developed severe inflammation in the gastric body, with no or weak inflammation in the antral mucosa at 6 weeks of age. nTx mice that developed inflammation were used for the following experiments.
Mononuclear cells infiltrated the lamina propria of the corpus mucosa 6 weeks after nTx in association with the production of autoantibodies against parietal cells (data not shown). As the inflammatory cells expanded along the glands, destruction of parietal cells and chief cells became prominent, resulting in glandular atrophy. There were no germinal centers observed, however, and the diffusely or massively infiltrating cells consisted mainly of lymphocytes and a few other mononuclear cells, including plasma cells and macrophages. These pathologic features remained unchanged throughout the experiment (Figure 1a). These observations are consistent with previous reports. ${ }^{8-12}$

After $H$. pylori infection, the gastric mucosa of the nTx mice was not significantly altered for the first 2 weeks. At 1 month (10 weeks of age) after infection,

Table 2 Lymphoid follicles, LELs, and Bcl- $\mathrm{X}_{\mathrm{L}}$ expression in the stomach of $H$. pylori-infected nTx Mice $(n=10)$

\begin{tabular}{llllc}
\hline & $2 M$ & $4 M$ & $6 M$ & $12 M$ \\
\hline Follicles $^{\mathrm{a}}$ & $6(60)$ & $4(40)$ & $8(80)$ & $9(90)$ \\
LELs $^{\mathrm{a}}$ & $6(60)$ & $8(80)$ & $9(90)$ & $10(100)$ \\
Bcl-X $_{\mathrm{L}}^{\mathrm{b}}$ & $0(0)$ & $0(0)$ & $2(20)$ & $8(80)$ \\
\hline
\end{tabular}

${ }^{\mathrm{a}}$ Follicles and LELs were examined histologically.

${ }^{\mathrm{b}} \mathrm{Bcl}-\mathrm{X}_{\mathrm{L}}$ expression in B lymphocytes was observed immunohistologically.

LEL: lymphoepithelial lesion; M: months after $H$. pylori infection; nTx: neonatally thymectomized.

Numbers of positive cases are shown. In all, 10 mice were studied for each time point. Values in parenthesis demonstrate percentages of positive cases.

Table 1 RT-PCR primers for heavy-chain immunoglobulin genes

\begin{tabular}{ll}
\hline Name & Sequence $\left(5^{\prime}-3^{\prime}\right)$ \\
\hline $\operatorname{MuIgV}_{\mathrm{H}} 5^{\prime}-\mathrm{A}$ & GGGAATTCATGRASTTSKGGYTMARCTKGRTTT \\
$\operatorname{MuIgV}_{\mathrm{H}} 5^{\prime}-\mathrm{B}$ & $\begin{array}{l}\text { GGGAATTCATGRAATGSASCTGGGTYWTYCTCTT } \\
\text { ACTAGTCGACATGGACTCCAGGCTCAATTTAGTTTCCT }\end{array}$ \\
$\operatorname{MuIgV}_{\mathrm{H}} 5^{\prime}-\mathrm{C}$ & ACTAGTCGACATGGCTGTCYTRGBGCTGYTCYTCTG \\
& ACTAGTCGACATGGVTTGGSTGTGGAMCTTGCYATTCCT \\
$\operatorname{MuIgV}_{\mathrm{H}} 5^{\prime}-\mathrm{D}$ & ACTAGTCGACATGAAATGCAGCTGGRTYATSTTCTT \\
& ACTAGTCGACATGGRCAGRCTTACWTYYTCATTCCT \\
$\operatorname{MuIgV}_{\mathrm{H}} 5^{\prime}-\mathrm{E}$ & ACTAGTCGACATGATGGTGTTAAGTCTTCTGTACCT \\
& ACTAGTCGACATGGGATGGAGCTRTATCATSYTCTT \\
$\operatorname{MuIgV}_{\mathrm{H}} 5^{\prime}-\mathrm{F}$ & ACTAGTCGACATGAAGWTGTGGBTRAACTGGRT \\
& ACTAGTCGACATGGRATGGASCKKIRTCTTTMTCT \\
$\operatorname{MuIgMV}_{\mathrm{H}} 3^{\prime}-1$ & ACTAGTCGACATGAACTTYGGGYTSAGMTTGRTTT \\
$\operatorname{MuIgGV}_{\mathrm{H}} 3^{\prime}-2$ & ACTAGTCGACATGTACTTGGGACTGAGCTGTGTAT \\
\hline
\end{tabular}

I: inosine; R: A or G; Y: C or T; K: G or T; S: C or G; M: A or C; W: A or T; B: C or G or T. 

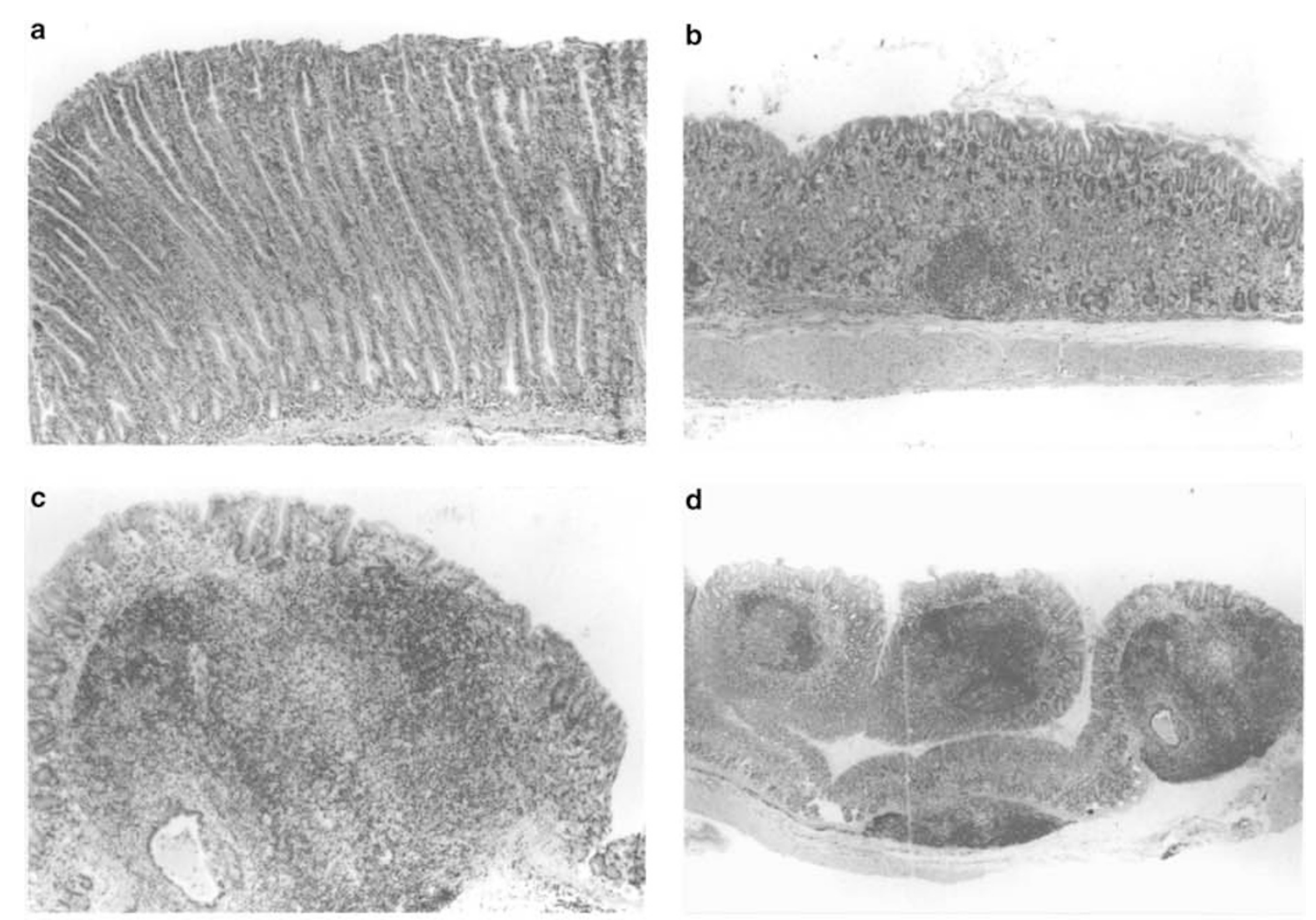

\section{a}

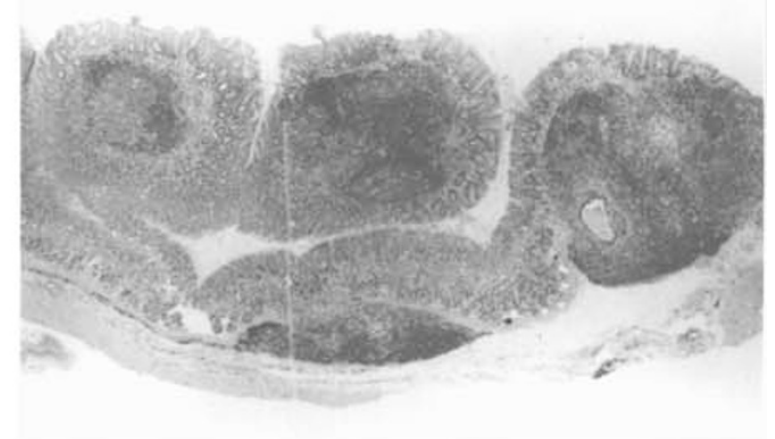

f
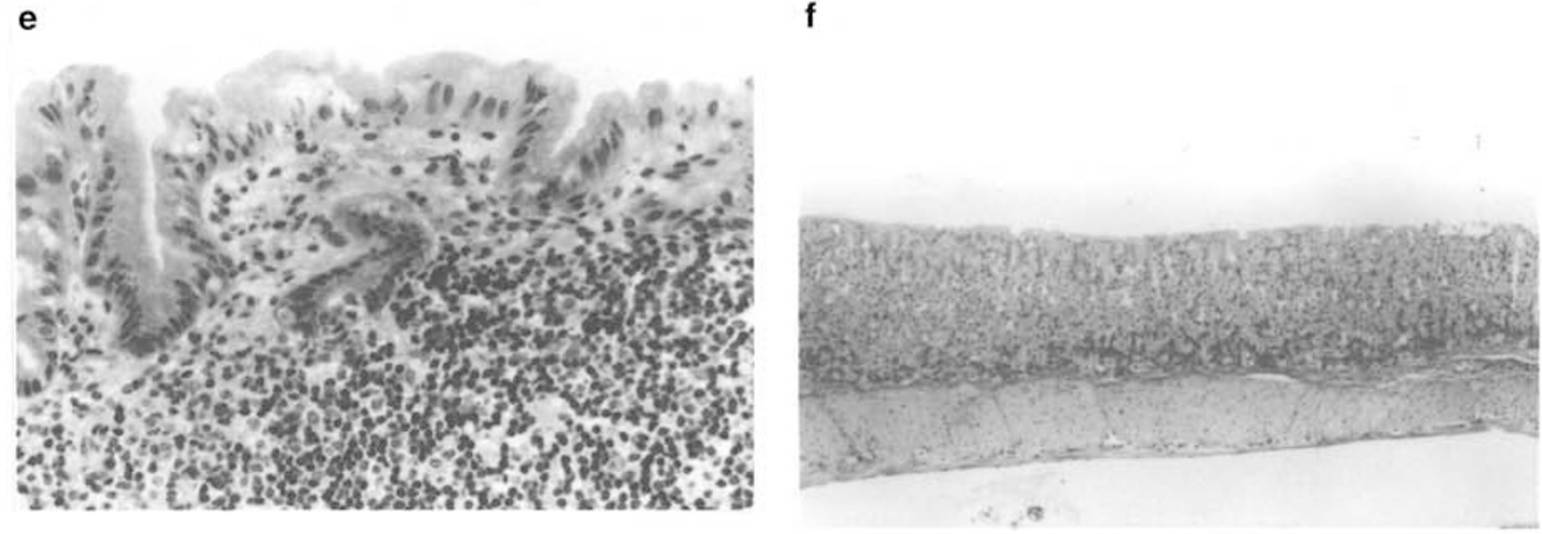

g

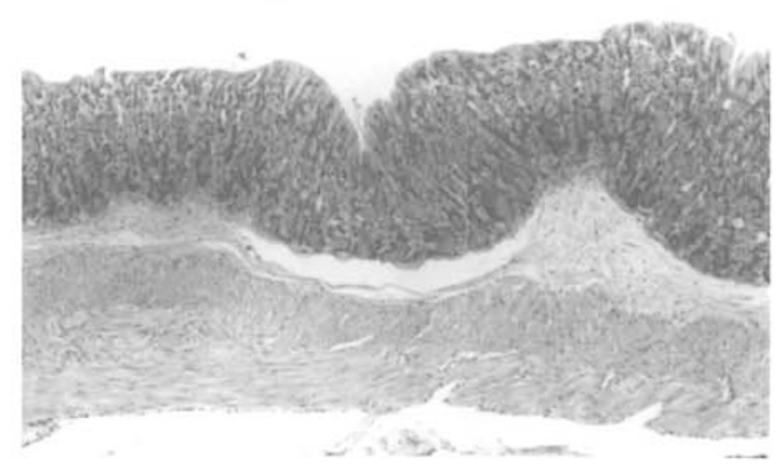


however, clusters of mononuclear cells appeared at the bottom of the lamina propria in the gastric mucosa as reported previously. ${ }^{5}$ There was a distinct change in lymphoid cell infiltration 2 months after infection (14 weeks of age, Figure 1b); unlike noninfected nTx mice, infected mice had lymphoid follicle development in the corpus mucosa. Follicle formation and infiltration of intraepithelial lymphocytes were enhanced in a time-dependent manner (follicles; $60 \%(6 / 10)$ at 2 months, $40 \%(4 / 10)$ at 4 months, $80 \%(8 / 10)$ at 6 months and $90 \%(9 / 10)$ at 12 months; Figure 1b-d), whereas no follicles formed in noninfected nTx mice throughout the experiment (Figure 1a). Lymphoepithelial lesions (LELs), a characteristic feature of human MALT lymphoma, were also observed in our model mice (LELs; $60 \%(6 / 10)$ at 2 months, $80 \%(8 / 10)$ at 4 months, $90 \%(9 / 10)$ at 6 months, and $100 \%(10 / 10)$ at 12 months; Figure 1e). On the other hand, there was little or no inflammation in the gastric mucosa of normal (non-nTx) mice irrespective of $H$. pylori infection (Figure 1f and g) throughout the experiment.

The phenotypes of the infiltrating mononuclear cells in the body mucosae of nTx mice noninfected or infected with $H$. pylori were analyzed by immunoperoxidase staining for CD4, CD8, and B220. A major portion of the lymphocytes infiltrating the gastric mucosa in both groups of mice for up to 12 months were $\mathrm{CD} 4^{+} \mathrm{T}$ cells, whereas a small number of $\mathrm{CD}^{+}$cells appeared in the later stages (data not shown). Although $H$. pylori infection did not significantly alter the distribution pattern of $\mathrm{T}$ cells, the most characteristic change was the formation of follicles with B cells (Figure 2a-c).

Staining for Bcl- $\mathrm{X}_{\mathrm{L}}$ protein was also performed in infected and noninfected $\mathrm{nTx}$ mice. Bcl- $\mathrm{X}_{\mathrm{L}}$ protein was overexpressed in the cytosol of the infiltrating B lymphocytes and in some follicular B lymphocytes at 6 and 12 months after infection $\left(\mathrm{Bcl}-\mathrm{X}_{\mathrm{L}} ; 20 \%(2 / 10)\right.$ at 6 months and $80 \%(8 / 10)$ at 12 months; Figure 2d). In contrast, noninfected nTx mice did not show any Bcl- $\mathrm{X}_{\mathrm{L}}$ immunoreactivity (Figure 2e).

Figure 1 Histology of gastric mucosa of $H$. pylori-infected nTx mice (hematoxylin and eosin staining). (a) The body mucosa of nTx mouse without $H$. pylori infection ( 2 months after saline administration instead of $H$. pylori), showing infiltration of mononuclear cells, gland atrophy characterized by the loss of parietal and chief cells, and hyperplasia of foveolar epithelium. Original magnification, $\times 100$. (b) and (c) Follicle formation in the body mucosa at 2 and 12 months after $H$. pylori infection in nTx mice, respectively. Original magnification, $\times 100$. (d) Massive follicles in the body mucosa at 12 months after $H$. pylori infection in nTx mouse. Original magnification, $\times 40$. (e) Massive lymphoepithelial lesions in $H$. pylori-infected nTx mouse (12 months after infection). Original magnification, $\times 400$. (f) and (g) Gastric mucosa of $H$. pylori noninfected and infected normal (non-nTx) mice (2 months after saline or $H$. pylori administration), respectively. No or very little lymphocyte infiltration was observed in both groups of mice. Original magnification, $\times 100$.

\section{Immunoelectrophoresis}

Serum immunoelectrophoresis revealed a monoclonal band (M-protein) in 30\% $(3 / 10)$ of nTx mice 6 months after infection. These serum M-proteinpositive mice certainly indicated gastric MALT lymphoma-like lesions. M-protein in the $\gamma$-region was identified to be IgG type (Figure 3).

\section{Detection of Heavy-chain Immunoglobulin Genes by RT-PCR}

M-protein-positive nTx mice 6 months after infection had amplification of one or two IgM and/or IgG heavy-chain genes of the gastric B lymphocytes, suggesting mono- or oligoclonality. In contrast, in noninfected nTx mice, all IgM and IgG primers tested were amplified equally, suggesting polyclonality (Figure 4).

\section{Discussion}

Several investigators have attempted to establish animal models of gastric MALT lymphoma induced by Helicobacter species. Erdman et a ${ }^{15}$ reported that $H$. mustelae might induce gastric MALT lymphoma in ferret. Enno et $a l^{16}$ reported that long-term infection with $H$. felis in normal BALB/c mice occasionally induced MALT lymphoma-like lesions without the preceding follicular gastritis. ${ }^{17}$ In their animal models, however, it took a long period of time to develop MALT lymphoma-like lesions, and moreover, the efficiency for developing the disease was unsatisfactory. In addition, precise genetic as well as immunologic analysis was not performed in the previous studies. Finally, the development of gastric MALT lymphoma-like lesions by $H$. pylori infection has not been reported. In previous studies, we succeeded in inducing lymphoid follicle formation in association with chronic gastritis by $H$. pylori infection in BALB/c mice that were thymectomized on the 3rd day after birth. ${ }^{5,12}$ In the present study, we extended our previous findings and established a model of gastric MALT lymphoma-like lesions after long-term infection with $H$. pylori using the same animals.

The diagnosis of human MALT lymphoma is based on pathologic criteria, which include reactive lymphoid follicles, LELs, centrocyte-like cells, and the same phenotype as marginal zone B cells (CD5 ${ }^{-}$, $\left.\mathrm{CD} 10^{-}, \mathrm{CD} 19^{+}, \mathrm{CD} 20^{+}\right)$. Genetic analysis such as detection of $\mathrm{t}(1 ; 14), \mathrm{t}(11 ; 18)$, trisomy 3 , and rearrangement of immunoglobulin heavy chains, and immunohistochemical analysis such as detection of restricted immunoglobulin light chains $(\kappa, \lambda)$ and positive bcl-2 and negative cyclin D1 staining are also helpful for the diagnosis of human MALT lymphoma. ${ }^{18-20}$ Our nTx BALB/c mice with chronic $H$. pylori infection for more than 6 months had reactive lymphoid follicles with massive LELs, 

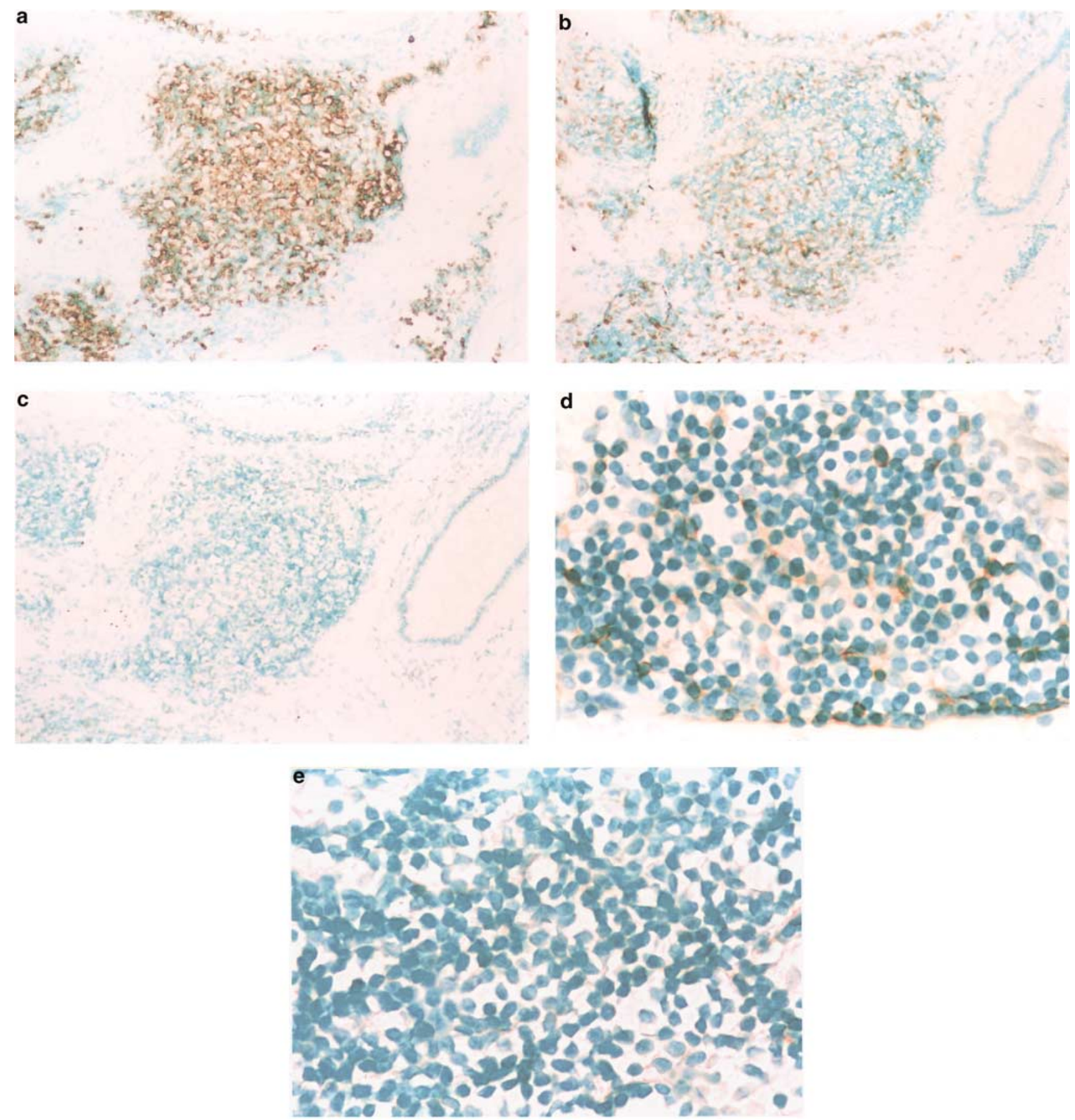

Figure 2 Immunohistochemical characterization of infiltrating lymphocytes in the gastric mucosa of $H$. pylori-infected nTx mice 12 months after infection. Massive B220 ${ }^{+}$cells (a), scattered CD4 ${ }^{+}$cells (b), and no CD8 ${ }^{+}$cells (c) were observed in lymphoid follicles. Original magnification, $\times 200$. Staining of Bcl- $\mathrm{X}_{\mathrm{L}}$ was observed in some follicular B lymphocytes 12 months after $H$. pylori infection (d), whereas no Bcl- $\mathrm{X}_{\mathrm{L}}$-positive B lymphocytes were observed in noninfected nTx mouse (e). Original magnification, $\times 1000$.

mono- or oligoclonality of immunoglobulin heavychain genes, positive Bcl- $\mathrm{X}_{\mathrm{L}}$ staining, a Bcl-2 family protein in the lymphoid follicles, and $\mathrm{M}$ proteinemia. These findings strongly suggest that gastric lesions induced by $H$. pylori infection in our mice are similar to human gastric MALT lymphoma.
The BALB/c mouse is a Th2-dominant strain for intracellular infections such as those by Leishmania major, whereas the C57BL/6J mouse is believed to be a Th1-dominant strain. ${ }^{21}$ In BALB/c mice, nTx depletes $\mathrm{CD}_{25}{ }^{+}$regulatory $\mathrm{T}$ cells in the periphery, which results in the development of Th1-dominant autoimmune atrophic gastritis with the loss of 


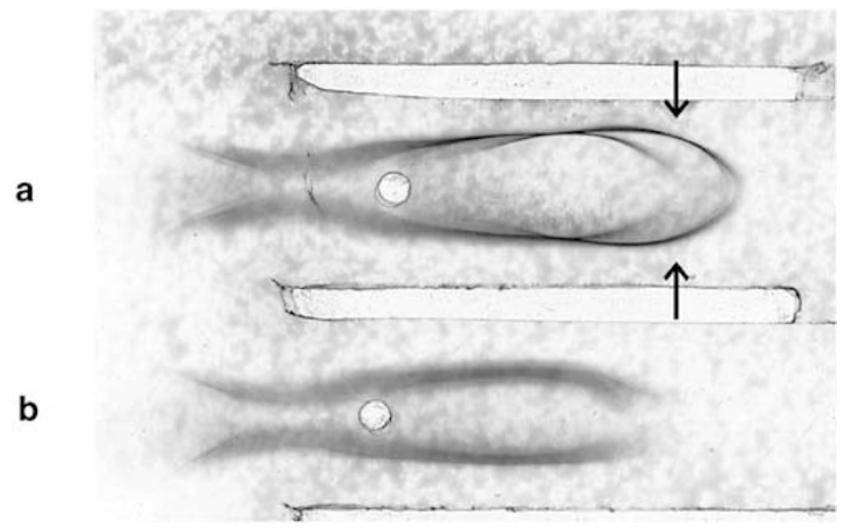

Figure 3 Serum immunoelectrophoresis of nTx mouse 6 months after $H$. pylori infection (a) and that without infection (b). A monoclonal band (M-protein) was observed in 30\% $(3 / 10)$ of the infected mice. Arrows indicate monoclonal bands.

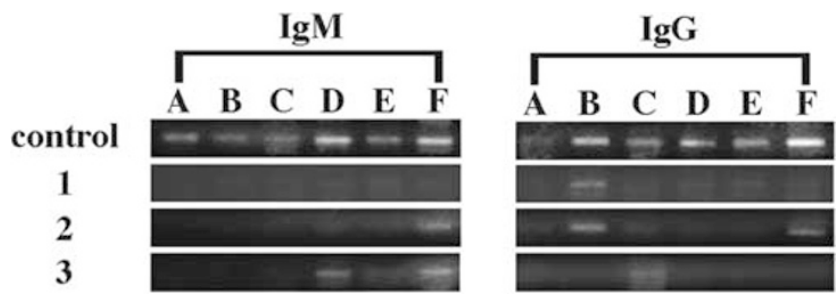

Figure 4 RT-PCR of specific IgM and IgG heavy-chain genes of the gastric B lymphocytes in nTx mice with or without $H$. pylori infection (6 months). Control shows positive bands for all primers used, whereas M-protein-positive mice (1-3) had amplification of one or two IgM and/or IgG heavy-chain genes, suggesting monoor oligoclonality. Control: a nTx mouse without infection. 1-3: M-protein-positive mice with $H$. pylori infection.

parietal and chief cells. ${ }^{22,23}$ In BALB/c mice, development of gastric MALT lymphoma-like lesions by $H$. pylori infection was observed in nTx mice but not in non-nTx mice. Moreover, lymphoid follicle formation by $H$. pylori infection was never observed in $\mathrm{C} 57 \mathrm{BL} / 6 \mathrm{~J}$ mice irrespective of $\mathrm{nTx}$, although these mice developed severe active gastritis by $H$. pylori infection, which is believed to be a typical Th1-type inflammation (data not shown). ${ }^{24-26}$ These data suggest that, in contrast to $H$. pylori-induced active gastritis, both Th1 and Th2 responses are necessary for the development of MALT lymphomalike lesions by $H$. pylori infection. Supporting this idea, we observed, in addition to IFN- $\gamma$, expression of IL-4, a representative Th2-type cytokine, in the gastric mucosa of only $H$. pylori-infected BALB/c mice with nTx that developed lymphoid follicles. ${ }^{5,12}$ Taken together, our previous and present findings suggest that genetic background and the resulting specific immune responses to $H$. pylori have critical roles in the development of MALT lymphoma-like lesions.

Overexpression of bcl-2 identified in human Bcell follicular lymphoma is associated with the translocation of $t(14 ; 18)$, which results in the prolongation of cell survival by inhibition of apoptosis. ${ }^{27}$ In addition, positive staining of Bcl-2 protein is observed in human MALT lymphoma. ${ }^{19,28,29}$ In a preliminary study, however, we performed immunohistochemical staining for Bcl-2 protein in our mice, but did not detect positive staining in infiltrating B cells (data not shown). Therefore, in the present study, we studied bcl- $\mathrm{X}_{\mathrm{L}}$, a bcl-2 family gene that is essential for the development of B cells by providing a survival signal for the maintenance of pre-B cells that becomes negative as they mature. $.^{30-32} \mathrm{Bcl}-\mathrm{X}_{\mathrm{L}}$ protein was not observed at 2 and 4 months after infection, but was clearly expressed in the MALT lymphoma-like lesions after 6 months. These data are compatible with the fact that in B-lymphocyte bcl- $\mathrm{X}_{\mathrm{L}} \mathrm{mRNA}$ is upregulated by administration of Helicobacter antigen in vitro. ${ }^{17}$ Thus, Bcl- $\mathrm{X}_{\mathrm{L}}$ might have an important role as an antiapoptotic molecule in the development of MALT lymphoma-like lesions in our mice.

In conclusion, our results demonstrated that gastric MALT lymphoma-like lesions developed in the gastric mucosa of $\mathrm{nTx}$ BALB/c mice after longterm $H$. pylori infection. This animal model appears to be useful for elucidating the mechanism for the development of gastric MALT lymphoma induced by $H$. pylori infection.

\section{Acknowledgement}

We authors acknowledge Mr H Koda for his help in preparing histological samples in the Department of Pathology and Biology of Diseases, Graduate School of Medicine, Kyoto University. This study was supported by a Grant-in-Aid for Scientific Research (Category) of the Ministry of Culture and Science of Japan (11670495), a Grant-in-Aid for 'Research for the Future' Program from The Japan Society for the Promotion of Science (JSPS-RFTF97I00201), Supporting Research Funds from The Japanese Foundation for Research and Promotion of Endoscopy (JFE1997), and the Shimidzu Immunology Foundation, 2000 .

\section{References}

1 Kuipers EJ, Uyterlinde AM, Pena AS, et al. Long-term sequelae of Helicobacter pylori gastritis. Lancet 1995;345:1525-1528.

2 Parsonnet J, Friedman GD, Vandersteen DP, et al. Helicobacter pylori infection and the risk of gastric carcinoma. N Engl J Med 1991;325:1127-1131.

3 Walsh JH, Peterson WL. The treatment of Helicobacter pylori infection in the management of peptic ulcer disease. N Engl J Med 1995;333:984-991.

4 Wotherspoon AC, Ortiz-Hidalgo C, Falzon MR, et al. Helicobacter pylori-associated gastritis and primary Bcell gastric lymphoma. Lancet 1991;338:1175-1176. 
5 Uchida K, Okazaki K, Debrecceni A, et al. Analysis of cytokines in the early development of gastric secondary lymphoid follicles in Helicobacter pylori-infected $\mathrm{BALB} / \mathrm{C}$ mice with neonatal thymectomy. Infect Immun 2001;69:6749-6754.

6 Nakamura T, Nakamura S, Yokoi T, et al. Clinicopathologic comparison between the API2-MALT1 chimeric transcript-positive and -negative gastric low-grade Bcell lymphoma of mucosa- associated lymphoid tissue type. Jpn J Cancer Res 2002;93:677-684.

7 Du MQ, Isaccson PG. Gastric MALT lymphoma: from aetiology to treatment. Lancet Oncol 2002;3:97-104.

8 Nishio A, Hosono M, Watanabe Y, et al. A conserved epitope on $\mathrm{H}+, \mathrm{K}(+)$-adenosine triphosphatase of parietal cells discerned by a murine gastritogenic T-cell clone. Gastroenterology 1994;107:1408-1414.

9 Jones CM, Callaghan JM, Gleeson PA, et al. The parietal cell autoantigens recognized in neonatal thymectomyinduced murine gastritis are the alpha and beta subunits of the gastric proton pump [corrected]. Gastroenterology 1991;101:287-294.

10 Katakai T, Mori KJ, Masuda T, et al. Differential localization of Th1 and Th2 cells in autoimmune gastritis. Int Immunol 1998;10:1325-1334.

11 Sakaguchi S, Fukuma K, Kuribayashi K, et al. Organspecific autoimmune diseases induced in mice by elimination of $\mathrm{T}$ cell subset. I. Evidence for the active participation of T cells in natural self-tolerance; deficit of a $\mathrm{T}$ cell subset as a possible cause of autoimmune disease. J Exp Med 1985;161:72-87.

12 Oshima C, Okazaki K, Matsushima Y, et al. Induction of follicular gastritis following postthymectomy autoimmune gastritis in Helicobacter pylori-infected BALB/c mice. Infect Immun 2000;68:100-106.

13 Watanabe T, Tada M, Nagai H, et al. Helicobacter pylori infection induces gastric cancer in mongolian gerbils. Gastroenterology 1998;115:642-648.

14 Scheidegger JJ. Une micro-methode de l'immunoelectrophorese. Int Arch Allergy 1955;7:103-110.

15 Erdman SE, Correa P, Coleman LA, et al. Helicobacter mustelae-associated gastric MALT lymphoma in ferrets. Am J Pathol 1997;151:273-280.

16 Enno A, O’Rourke JL, Howlett CR, et al. MALToma-like lesions in the murine gastric mucosa after long-term infection with Helicobacter felis. A mouse model of Helicobacter pylori-induced gastric lymphoma. Am J Pathol 1995;147:217-222.

17 Morgner A, Sutton P, O’Rourke JL, et al. Helicobacterinduced expression of Bcl-X(L) in B lymphocytes in the mouse model: a possible step in the development of gastric mucosa- associated lymphoid tissue (MALT) lymphoma. Int J Cancer 2001;92:634-640.

18 Cavalli F, Isaacson PG, Gascoyne RD, et al. MALT Lymphomas. Hematology (Am Soc Hematol Educ Program) 2001; 241-258.
19 Maes B, De Wolf-Peeters C. Marginal zone cell lymphoma-an update on recent advances. Histopathology 2002;40:117-126.

20 Morgner A, Bayerdorffer E, Neubauer A, et al. Gastric MALT lymphoma and its relationship to Helicobacter pylori infection: management and pathogenesis of the disease. Microsc Res Technol 2000;48: 349-356.

21 Heinzel FP, Sadick MD, Holaday BJ, et al. Reciprocal expression of interferon gamma or interleukin 4 during the resolution or progression of murine leishmaniasis. Evidence for expansion of distinct helper $\mathrm{T}$ cell subsets. J Exp Med 1989;169:59-72.

22 McHugh RS, Shevach EM. Cutting edge: depletion of CD4+CD25+ regulatory $\mathrm{T}$ cells is necessary, but not sufficient, for induction of organ-specific autoimmune disease. J Immunol 2002;168:5979-5983.

23 Suri-Payer E, Amar AZ, Thornton AM, et al. CD4+CD25+ T cells inhibit both the induction and effector function of autoreactive T cells and represent a unique lineage of immunoregulatory cells. J Immunol 1998;160:1212-1218.

24 Fox JG, Li X, Cahill RJ, et al. Hypertrophic gastropathy in Helicobacter felis-infected wild-type C57BL/6 mice and p53 hemizygous transgenic mice. Gastroenterology 1996;110:155-166.

25 Mohammadi M, Redline R, Nedrud J, et al. Role of the host in pathogenesis of Helicobacter-associated gastritis: $H$. felis infection of inbred and congenic mouse strains. Infect Immun 1996;64:238-245.

26 Sakagami T, Dixon M, O’Rourke J, et al. Atrophic gastric changes in both Helicobacter felis and Helicobacter pylori infected mice are host dependent and separate from antral gastritis. Gut 1996;39: 639-648.

27 Tsujimoto Y, Cossman J, Jaffe E, et al. Involvement of the bcl-2 gene in human follicular lymphoma. Science 1985;228:1440-1443.

28 Ashton-Key M, Biddolph SC, Stein H, et al. Heterogeneity of bcl-2 expression in MALT lymphoma. Histopathology 1995;26:75-78.

29 Navratil E, Gaulard P, Kanavaros P, et al. Expression of the bcl-2 protein in B cell lymphomas arising from mucosa associated lymphoid tissue. J Clin Pathol 1995;48:18-21.

30 Choi MS, Holmann M, Atkins CJ, et al. Expression of blc-x during mouse B cell differentiation and following activation by various stimuli. Eur J Immunol 1996;26: 676-682.

31 Merino R, Ding L, Veis DJ, et al. Developmental regulation of the Bcl-2 protein and susceptibility to cell death in B lymphocytes. EMBO J 1994;13: 683-691.

32 Osmond DG. B cell development in the bone marrow. Semin Immunol 1990;2:173-180. 